\title{
Valorização do patrimônio científico e tecnológico brasileiro: descobrindo conjuntos de objetos de C\&T pelo Brasil
}

\author{
Marcus Granato ${ }^{1}$ \\ Elias da Silva Maia $^{2}$ \\ Fernanda Pires Santos ${ }^{3}$
}

RESUMO: A maior parte dos bens que constituem o patrimônio cultural da Ciência e Tecnologia (C\&T) está para ser descoberta. $\bigcirc$ conhecimento acumulado sobre o tema ainda é limitado e há um risco real de que os objetos já tenham sido modernizados ou descartados. Nos últimos quatro anos, desenvolveu-se um projeto de pesquisa, envolvendo várias iniciativas para preservar este tipo de patrimônio: um levantamento nacional para construir um panorama do estado atual desse patrimônio; estudos sobre a legislação de proteção ao patrimônio de alguns países, inclusive o Brasil; e dois estudos de caso de coleções de objetos de C\&T (Observatório do Valongo e Colégio Pedro II, ambos no Rio de Janeiro). Este artigo apresenta uma visão geral dos resultados obtidos e, em especial, dos levantamentos de conjuntos de objetos de C\&T. Utilizou-se um recorte em relação a áreas do conhecimento e período histórico, compreendendo objetos pertencentes às ciências exatas, às diferentes especialidades de engenharia, bem como geografia, geologia e oceanografia, e fabricados até 1960. A partir da adaptação de um formulário usado em pesquisas similares em Portugal, elaborou-se uma ficha de registro, que permitiu identificar conjuntos de objetos em museus, universidades e institutos de pesquisa. Pôde-se, com isso, observar que as coleções mais bem preservadas estão nos poucos museus dedicados à área, enquanto as universidades detêm a maior parte dos artefatos, e que a esmagadora maioria dos objetos foi produzida no século XX.

PALAVRAS-CHAVE: Museologia. Patrimônio Científico. Preservação. MAST.

ABSTRACT: Most of Brazil's science and technology (S\&T) heritage has yet to be tracked down. The knowledge amassed on the topic is still limited, and there is a real risk that Brazilian science and technology objects may already have been modernized or discarded. A research project was developed in the last four years including several initiatives to preserve this kind of heritage, as such: a national survey to build up a picture of the current state of this heritage; studies concerning heritage protection legislation of some countries, including Brazil; and two case studies of collections of S\&T objects (Observatório do Valongo and Colégio Pedro II). This paper presents an overview of the results obtained in the several initiatives of preservation undertaken. The
1. Engenheiro metalúrgico (UFRJ), mestre e doutor em Engenharia Metalúrgica (COPPE/UFRJ), coordenador de Museologia do Museu de Astronomia e Ciências Afins - MAST, vice-coordenador e professor do programa de Pós-Graduação em Museologia e Patrimônio (UNIRIO/MAST), bolsista de produtividade $1 \mathrm{C}$ do $\mathrm{CNPq}$, líder do Grupo de Pesquisa Preservação de Acervos Culturais. E-mail: <marcus@ mast.br>

2. Historiador, mestre em História (UFF). Doutorando em História da Ciência (UFRJ).E-mail: <esmaia@ ig.com.br>

3. Historiadora, mestre em Museologia e Patrimônio (UNIRIO/MAST), bolsista do Programa de Capacitação Institucional do MAST. E-mail:<fernandasantos@ mast.br> 
4. Ver Teresa Scheiner (2007, p. 36).

5. "Em relação ao que constitui patrimônio de C\&T, consideramos o conhecimento científico e tecnológico produzido pelo homem, além de todos aqueles objetos (inclusive documentos em suporte papel), coleções arqueológicas, etnográficas e espécimes das coleções biológicas que são testemunhos dos processos científicos e do desenvolvimento tecnológico. Também se incluem nesse grande conjunto as construções arquitetônicas produzidas com a funcionalidade de atender às necessidades desses processos e desenvolvimentos." Cf. Marcus Granato (2009, p. 79).

6. Projeto Valorização do Patrimônio Científico e Tecnológico Brasileiro. survey is divided into different areas of knowledge and different time frames. As such, we are interested in sets of objects from the exact sciences, the different engineering specialties, as well as geography, geology and oceanography, which were manufactured in or before the 1960s. A registration form was prepared which was adapted from a form used in surveys of collections of this kind in Portugal. Sets of objects have been identified at museums, universities and research institutes. From the results, it could be observed that: the best preserved collections are at the few museums devoted to the area, but the universities hold most of the artifacts and the overwhelming majority of the objects were made in the twentieth century.

KEYWORDS: Museology. Scientific Heritage. Preservation. Surveying. MAST.

\section{Introdução}

patrimônio cultural de um país inclui todos os bens que possuem valores culturais (estético, artístico, científico, arquitetônico, histórico etc.) para a sua sociedade. Incorpora, assim, o conjunto de produções materiais e imateriais do ser humano e seus contextos sociais e naturais, que constituem objeto de interesse a ser preservado para as futuras gerações. Scheiner, no âmbito das novas formas de comunicação e do universo virtual, considera o patrimônio "não mais como um conjunto de valores atribuídos ao espaço geográfico e aos produtos do fazer humano, mas como um valor plural, ao qual estão sendo atribuídas novas significações" ${ }^{\prime 4}$.

No campo desses novos significados e dos novos patrimônios, se inserem os bens materiais e os valores sobre os quais se debruça este trabalho, especificamente o patrimônio cultural de Ciência e Tecnologia ${ }^{5}$ (C\&T). As pesquisas desenvolvidas e aqui relatadas ${ }^{6}$ se dedicaram a estudar os bens produzidos e/ou utilizados nas atividades de pesquisa científica e de desenvolvimento tecnológico. Ou seja, aqueles bens que participaram do cotidiano dos laboratórios de pesquisa do país e contribuíram para o desenvolvimento da ciência e tecnologia no Brasil. Tais bens estão em centros de pesquisa, nas universidades, nas escolas técnicas e, em sua maioria, não têm seu valor reconhecido. Por outro lado, uma parte deles encontra-se em museus e já está sendo preservada para o futuro. Algumas imagens características de objetos pertencentes a esse universo são apresentadas na Figura 1 a seguir.

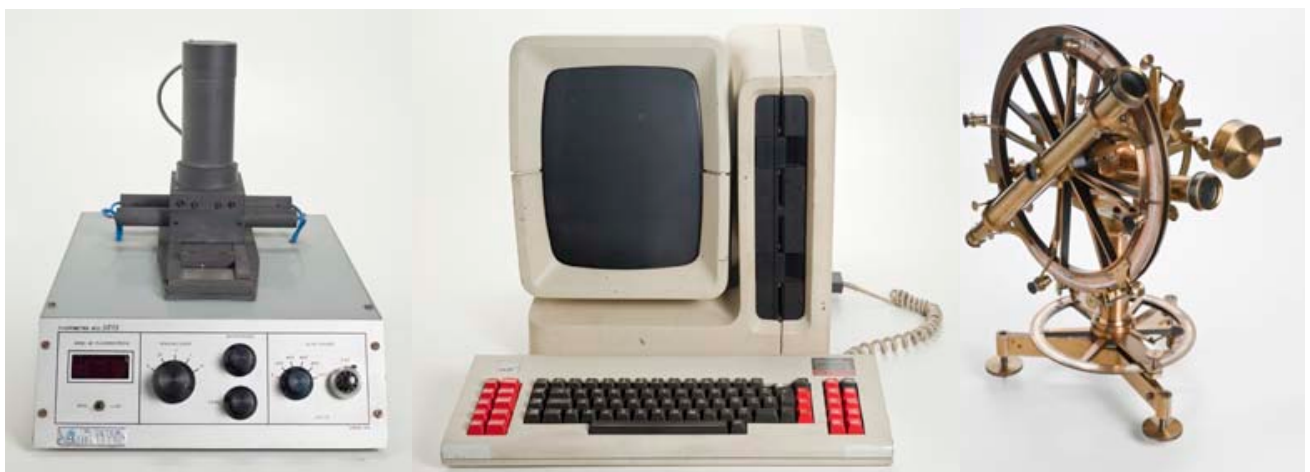

Figuras 1a, 1b e 1c: Objetos de C\&T da coleção do MAST, fluorímetro, computador e teodolito. (Acervo MAST). 
Lourenço e Wilson também relacionam o que poderia ser incluído nessa categoria de patrimônio cultural:

It includes human-made buildings and landscapes of historical significance, such as astronomical and geophysical observatories, meteorological stations, laboratories, and botanical gardens. But it also includes herbaria, fossils, bones, eggs, pollens, wax and teaching models, minerals, rocks, meteorites, scientific instruments of all types, soil samples, animals, plants and seed, tissue and DNA banks, among many others?.

Como se percebe, a variedade de itens é imensa, mas os resultados aqui apresentados estão relacionados somente a uma parte desse grande conjunto de materialidades, os chamados objetos de Ciência e Tecnologia ${ }^{8}$ (C\&T). Conforme dito anteriormente, esses resultados advêm de um período de quatro anos de atividades do Projeto Valorização do Patrimônio Científico e Tecnológico Brasileiro. Como pouco se sabia sobre o assunto, foi realizado um levantamento de âmbito nacional para identificar quais instituições ainda possuíam objetos que poderiam ser preservados, qual a sua condição e em que número seriam. A constatação é surpreendente. A maior parte dos objetos de C\&T anteriores ao século XX já se perdeu. $\bigcirc$ que ainda resta está protegido nos museus. Por outro lado, existe um grande número desses objetos que, embora mais recentes, estão em situação de abandono, especialmente, nas universidades e institutos de pesquisa.

O projeto também fez um estudo das legislações de proteção desse tipo de patrimônio no Brasil e em vários outros países, como Argentina, México, Peru, Cuba, França, Inglaterra, Portugal, Espanha, China', o que possibilitou encontrar formas jurídicas interessantes que poderiam complementar as leis brasileiras. Finalmente, foram escolhidos dois conjuntos de objetos ${ }^{10}$ de C\&T, pertencentes ao Observatório do Valongo (UFRJ, RJ) e ao Colégio Pedro II (unidade Centro, RJ) ${ }^{11}$, para estudo e construção de suas biografias coletivas' ${ }^{12}$.

No presente texto serão privilegiados os resultados obtidos no levantamento nacional de conjuntos de objetos de C\&T.

\section{Procedimentos para levantamento de grupos de objetos de C\&T}

Surveys are essential tools for future preservation planning, policies, management and research. Their aim is to identify relevant clusters that are dispersed and characterize them according to a variety of parameters (e.g. number of objects, institutional status, location, conservation and security state, relevance, and use) ${ }^{13}$.

Realizar a preservação de bens culturais somente é possível a partir do conhecimento de sua existência e de onde se encontram. Para tal, é necessário empreender jornadas de identificação, os chamados levantamentos, como primeira etapa para sua salvaguarda. No que diz respeito ao patrimônio cultural de C\&T, esse tipo de iniciativa praticamente inexistia no Brasil, mas, no exterior, especialmente
7. "Inclui edifícios feitos pelo homem e espaços de importância histórica, como observatórios astronômicos e geofísicos, estações meteorológicas, laboratórios e jardins botânicos. Mas também inclui herbários, fósseis, ossos, ovos, pólen, modelos de cera e de ensino, minerais, rochas, meteoritos, instrumentos científicos de todos os tipos, amostras de solo, animais, plantas e bancos de sementes, tecidos e DNA, entre muitos outros." Cf. Marta Lourenço; Lydia Wilson (2013, p. 745); tradução dos autores.

8. Os objetos mais facilmente identificados ao patrimônio cultural de C\&T são os denominados instrumentos científicos, pois fazem parte das atividades realizadas em laboratórios científicos e de tecnologia aplicada. No entanto, instrumento científico é um termo complexo e que só se aplica em período histórico determinado (século XIX e início do século XX). De forma mais geral, utilizar-se-á a nomenclatura de objetos de Ciência e Tecnologia, por ser mais ampla e englobar a variedade de artefatos considerados nesse estudo. Ver Marcus Granato e colaboradores (2007).

9. Para acesso aos resultados, ver Pedro Louvain e Marcus Granato (2013).

10. Define-se aqui um conjunto como um grupamento de objetos de C\&T que pode ter valor cultural. Trata-se, pois, de um termo geral que compreende grupos de objetos organizados ou não, acessíveis ou não ao público. Assim, em seus extremos, se inserem tanto coleções musealizadas e quanto agrupamentos de objetos desorganizados, inacessíveis, ou mesmo abandonados.

11. Para acesso aos resultados, ver Maria Alice Oliveira e Marcus Granato (2011); 
Idem (2012); Marcus Granato e colaboradores (2013).

12. A utilização da prosopografia, ou biografia coletiva, para estudar objetos de C\&T foi proposta por Jim Bennett (2005), historiador de coleções e museus de história natural, e consiste em analisar os objetos em seus caminhos e/ou descaminhos antes e depois de sua incorporação a uma coleção.

13. "Levantamentos são ferramentas essenciais para o futuro planejamento da preservação, de políticas, de gerenciamento e da pesquisa. Seu objetivo é identificar agrupamentos que estão dispersos e caracterizá-los, de acordo com uma série de parâmetros (por exemplo, número de objetos, status institucional, localização, estado de conservação e segurança, relevância e uso)." Marta Lourenço e Lydia Wilson (2013, p. 746); tradução dos autores.

14. A colaboração entre o MAST e o Museu de Ciências da Universidade de Lisboa se desenvolve na área de Museologia e Patrimônio desde 2000, possibilitando inclusive a realização de projetos conjuntos - Projeto Thesaurus de Acervos Científicos em Língua Portuguesa; para saber mais ver: Granato e colaboradores (2013a) - e de publicações de referência sobre as coleções científicas brasileiras e portuguesas. Ver Marcus Granato; Marta Lourenço (2010).

15. Ver Marta Lourenço e Lydia Wilson (2013, p. 726).

16. Ver Sebastian Soubirane colaboradores (2009).

17. Desenvolvida no âmbito do Office de Coopération et Information Muséales ONCIM (Escritório Francês de Cooperação e Informação para Museus). Disponível em: http://www. no ambiente universitário, percebe-se uma situação diferente. Daí o trabalho de levantamento que será aqui apresentado inspirar-se em iniciativas europeias, sobretudo, nas primeiras identificações de patrimônio universitário português, realizadas pelo Museu de Ciências da Universidade de Lisboa, sob coordenação da pesquisadora Marta Lourenço ${ }^{14}$. Apesar do âmbito diverso, já que no caso português o objetivo são as universidades e suas inúmeras áreas de conhecimento, a perspectiva é similar, debruçar-se sobre o patrimônio científico e que está em situação de abandono.

Os primeiros levantamentos em torno desse tipo de patrimônio de que se tem notícia foram realizados na década de 1990, na Holanda, Reino Unido e Austrália ${ }^{15}$. Mais tarde, outros países europeus seguiriam o exemplo, tanto que, hoje em dia, o conhecimento sobre o patrimônio universitário, europeu, em particular, é bastante amplo e muito mais completo se comparado com o que aqui se discute, incluindo outras tipologias, como o patrimônio artístico e o da saúde ${ }^{16}$.

Em relação à preservação do patrimônio científico e técnico, há que se destacar ainda algumas iniciativas francesas. Encontra-se disponível na internet uma plataforma que disponibiliza dados sobre acervos universitários franceses Plateforme OCIM Universités ${ }^{17}$. Além disso, estão em andamento dois programas nacionais para a preservação do patrimônio científico e que incluem levantamentos, sendo um voltado para o patrimônio recente da ciência, coordenado pelo Musée des Arts et Métiers ${ }^{18}$, e outro, ao patrimônio das escolas de ensino médio ${ }^{19}$, coordenado pela Association de Sauvegarde et d'Étude des Instruments Scientifiques et Techniques de l'Enseignement ${ }^{20}$.

Por fim, cabe mencionar a iniciativa alemã que talvez possa ser considerada a mais produtiva, em termos de resultados concretos. Um levantamento nacional de patrimônio universitário foi iniciado em 2004 pelo Helmholtz Zentrum für Kulturtechnik da Universidade de Humboldt, em Berlim, financiado pela Fundação de Pesquisa Alemã (DFG)21. Num primeiro momento, infelizmente, muitas universidades não conseguiram nem mesmo produzir uma listagem de suas coleções. $\bigcirc$ trabalho de identificar e documentar esses conjuntos de bens levou vários anos e permitiu verificar a existência de 819 coleções nas universidades e de outras 300 que haviam sido perdidas de formas diversas ${ }^{22}$.

Em 2011 , sete anos após o início dessa iniciativa, a agência federal de pesquisa alemã (Wissenschaftsrat - German Council for the Sciences and Humanities) reconheceu publicamente que as coleções científicas fazem parte da infraestrutura para pesquisa e que sua preservação é atividade fundamental das instituições que possuem sua guarda ${ }^{23}$. Uma das recomendações do Conselho Alemão foi a criação de um centro que coordenasse e centralizasse os esforços de preservação, além de disponibilizar fundos em nível nacional para dar suporte a tal atividade. E o que, hoje, nos parece quase impossível em nosso país, ocorreu na Alemanha. Em 2012, financiado pelo Ministério da Educação e Pesquisa, o centro de coordenação iniciou suas atividades, propiciando uma perspectiva nova para o patrimônio científico alemão ${ }^{24}$. 
O levantamento de conjuntos de objetos de C\&T aqui realizado em nível nacional caracteriza-se como uma iniciativa similar a todas essas anteriormente apresentadas. Apesar de contar com algum auxilio de agências financiadoras (CNPq e FAPERJ), os recursos disponibilizados foram mínimos, face à tarefa pretendida. E, mesmo com uma complementação do MAST, percebe-se que, para percorrer todo o país, seria necessária uma equipe maior e com mais recursos, a fim de que o panorama obtido pudesse ser mais detalhado e completo.

Entretanto, cabe ressaltar que as iniciativas empreendidas no exterior sempre se deram em âmbito universitário, enquanto, no Brasil, uma gama bem maior de instituições foi objeto de interesse dos levantamentos, sem contar as dimensões continentais brasileiras que ampliam o desafio a ser enfrentado. Ainda assim, os resultados são auspiciosos e estimulam a continuação dos esforços em prol da preservação desses conjuntos de objetos.

\section{1. Metodologia}

Com vistas a estabelecer um procedimento de trabalho, inicialmente, delimitou-se o universo de interesse da pesquisa. Para isso, foram estipulados dois cortes, um cronológico e outro por áreas do conhecimento. Assim, integram o conjunto de objetos candidatos a constituírem parte do patrimônio cultural de C\&T brasileiro, a partir dos levantamentos realizados, aqueles produzidos até a década de 1960 e que pertençam às ciências exatas e da terra e engenharias. Tal delimitação tem relação com os seguintes aspectos:

- o corte temporal liga-se ao fato de que objetos mais recentes poderão ainda estar em uso em seus locais originais, o que os retira do campo de interesse do projeto; - o corte de áreas do conhecimento refere-se às áreas de atuação do próprio Museu de Astronomia e Ciências Afins, ou às áreas que podem contribuir para seu acervo.

Após a delimitação, foram avaliadas e discutidas as formas de registrar os conjuntos de objetos de interesse da pesquisa e analisadas algumas experiências de levantamentos de patrimônio científico realizadas na Europa. Decidiu-se utilizar como base uma ficha de registro desenvolvida em Portugal e, a partir dela, fez-se uma discussão no sentido de adaptar alguns aspectos às características do caso brasileiro (Anexo).

Estabelecidas as parcerias com as Escolas de Museologia de algumas universidades federais - UFPE, UFBA, UFPEL, UNB e UFOP -, foram, então, repassadas a metodologia, a ficha de registro e instruções para as equipes dessas instituições realizarem os levantamentos, respectivamente, nos estados de Pernambuco, Bahia, Rio Grande do Sul, Goiás/ Distrito Federal e Minas Gerais. Em alguns estados, os levantamentos não produziram resultados definitivos, exigindo uma continuidade dos trabalhos complementados pela equipe do MAST.

No processo de desenvolvimento dos levantamentos, foram feitos contatos com instituições possíveis detentoras desse patrimônio, a fim de conscientizá-las de seu valor e propiciar a realização da identificação desses ocim.fr/. Acesso em: 12 fev. 2014 .

18. Ver Catherine Ballé; Catherine Cuenca e Daniel Thoulouze (2010).

19. Disponível em: http:// www.aseiste.org/. Acesso em: 13 de fev. 2014.

20. Ver Francis Girese Pierre Lauginie (2013).

21. Ver Oliver Zauzig (2013, p. 2).

22. Idem (p. 3).

23. Ver Scientific Collections as Research Infrastructure, German Council for the Sciences and Humanities, Disponível em: http://www. wissenschaftsrat.de/download/archiv/10464-11-11_ engl.pdf. Acesso em: 13 fev. 2014.

24. Ver Oliver Zauzig (2013, p. 5). 
25. Brasil. (Portaria Normativa ${ }^{\circ} 40$, de $12 \mathrm{dez}$. 2007). objetos com vistas à sua proteção e reconhecimento. As universidades apresentam um grande potencial para exploração, assim como as instituições de pesquisa. Também foram incluídas nos levantamentos as instituições militares.

Para identificação do patrimônio cultural relacionado à ciência e tecnologia, realizaram-se buscas por meio de correio eletrônico, contato telefônico e visitas presenciais. As instituições consideradas estavam inseridas em quatro tipologias: Instituições de Ensino Superior (IES), Institutos de Pesquisa Científica e/ ou Tecnológica (ICT), Instituições Museológicas (MUS) e Instituições de Ensino Médio (IEM). É importante mencionar que as IEM não foram priorizadas nesse primeiro momento, em função do grande universo a ser avaliado. A seguir, serão apresentados os critérios utilizados no recorte do universo da pesquisa.

Para levantamento dos objetos de C\&T pertencentes às universidades (IES) brasileiras, foram utilizados os seguintes critérios:

a) Levantamento das universidades brasileiras constantes do E-MEC. $O$ E-MEC foi criado por meio da Portaria N $N^{0} 40$ (12/12/2007) $)^{25}$ para instituir o cadastro de instituições e cursos superiores. Sua utilização como fonte se justifica por tratar-se da base de dados oficial e única com informações relativas às instituições e cursos de educação superior, mantida pelo Ministério da Educação. No cadastro, foram selecionadas as instituições consideradas como pública federal laquelas mantidas pelo Poder Público Federal, com gratuidade de matrículas e mensalidades) e pública estadual (mantidas pelo Poder Público Estadual, com gratuidade de matrículas e mensalidades).

b) Nas instituições federais e estaduais cadastradas no E-MEC, foram identificados e selecionados os departamentos e cursos concernentes às grandes áreas Ciências Exatas e da Terra e Engenharias, conforme classificação da Coordenação de Aperfeiçoamento de Pessoal de Nível Superior. É preciso ressaltar que a classificação original dessas áreas apresenta uma hierarquização em quatro níveis, do mais geral aos mais específicos, abrangendo oito grandes áreas, 76 áreas e 340 subáreas do conhecimento. A seguir é apresentada a Tabela 1 contendo aquelas contempladas na pesquisa.

Tabela 1: Grandes áreas e áreas do conhecimento contempladas nos levantamentos realizados no projeto.

\begin{tabular}{|l|l|}
\hline \multicolumn{1}{|c|}{ Grande Área $\left(7^{\circ}\right.$ nível) } & \multicolumn{1}{|c|}{ Área de Avaliação (2 nível) } \\
\hline & Matemáticas \\
Ciências Exatas e da Terra & Física \\
& Química \\
& Geociências \\
\hline
\end{tabular}




\begin{tabular}{|l|l|}
\hline Engenharias & $\begin{array}{l}\text { Engenharia Civil } \\
\text { Engenharia Sanitária } \\
\text { Engenharia de Transporte }\end{array}$ \\
\hline Engenharias II & $\begin{array}{l}\text { Engenharia de Minas } \\
\text { Engenharia Materiais e Metalúrgica } \\
\text { Engenharia Química } \\
\text { Engenharia Nuclear }\end{array}$ \\
\hline Engenharias III & $\begin{array}{l}\text { Engenharia Mecânica } \\
\text { Engenharia de Produção } \\
\text { Engenharia Naval e Oceânica } \\
\text { Engenharia Aeroespacial }\end{array}$ \\
\hline Engenharias IV & Engenharia Elétrica \\
\hline
\end{tabular}

Fonte: Tabela de Áreas de Conhecimento da CAPES ${ }^{26}$.

Para levantamento dos objetos de C\&T existentes nos museus brasileiros (MUS), utilizou-se o levantamento dos museus brasileiros constantes do Cadastro de Museus do Instituto Brasileiro de Museus (IBRAM). $\bigcirc$ projeto do Cadastro Nacional de Museus, criado em 2006, tem por finalidade conhecer e mapear a diversidade museológica brasileira. No Projeto Valorização do Patrimônio, fez-se uso do Guia dos Museus Brasileiros, publicação de 2011 que contém os museus presenciais, virtuais e instituições em implantação constantes da referida base de dados. Aqui são considerados museus presenciais as instituições que ocupam um território e que, nesse espaço, desenvolvem ações de preservação, comunicação e pesquisa de bens culturais. Do referido guia, foram selecionados os museus que possuíam no item "tipologia do acervo" as categorias "ciência e tecnologia" e "história", além de museus municipais.

Para levantamento dos objetos de C\&T pertencentes às instituições de pesquisa (ICT), utilizou-se a listagem das instituições cadastradas no Programa de Informação e Comunicação para Ciência e Tecnologia - Prossiga. $\bigcirc$ Prossiga, criado pelo IBICT, tem como objetivo principal organizar e disseminar informações para a gestão de ciência, tecnologia e inovação. Dentre as ações do programa, encontram-se, em seu site na internet, dados cadastrais sobre instituições de C\&T e seus órgãos subordinados, principalmente sobre as de ensino superior, de pesquisa e institutos tecnológicos. De acordo com Relatório de Atividade de 2002, foram incluídos 5.416 registros na base de dados pela Rede Prossiga nos estados totalizando 24.280 instituições com suas unidades administrativas. No Projeto Valorização do Patrimônio, foram identificadas aquelas instituições referentes às grandes áreas de conhecimento já mencionadas para identificação do acervo disponível. 
27. É importante mencionar que os números aqui apresentados não são definitivos, pois a pesquisa realizada no projeto é dinâmica e novos locais com conjuntos de objetos de C\&T podem ser identificados, determinando sua alteração.
Nos levantamentos dessas instituições também foram utilizadas as seguintes fontes: portais das prefeituras das cidades e dos governos dos estados brasileiros na internet; sites de busca na web.

Concluído o levantamento de instituições potencialmente guardiãs de conjuntos de objetos de C\&T, separadas por estados e tipologias, foram feitos os primeiros contatos via e-mail e, posteriormente, por telefone. Quando a instituição confirmava possuir instrumentos interessantes ao projeto, fazia-se a tentativa de registrá-la, mesmo por telefone ou e-mail, valendo-se da ficha de registro previamente elaborada, como já descrito no subitem anterior. Na maioria dos casos isso se mostrava pouco eficaz, determinando a necessidade de visitas presenciais aos locais.

3. Resultados gerais dos levantamentos de conjuntos de objetos de C\&T

Quanto ao tipo de instituição, do total de 1.486 contatos potenciais identificados, 834 foram classificados como Instituições de Ensino Superior - IES (56, 1\% do total); 470 foram considerados Museus - MUS (31,6\%); 161, Instituições de Pesquisa Científica e/ou Tecnológica - ICT (10,9\%) e 21, Instituições de Ensino Médio - IEM (1,4\%).

Em relação à existência, nessas instituições, de conjuntos de artefatos de interesse para o projeto, o gráfico apresentado na Figura 2 mostra os resultados obtidos, sendo que os contatos inviáveis se referem àqueles casos em que, apesar das inúmeras tentativas da equipe de pesquisa, não foi possível obter e-mails e/ ou telefones que permitissem um resultado conclusivo e produtivo.

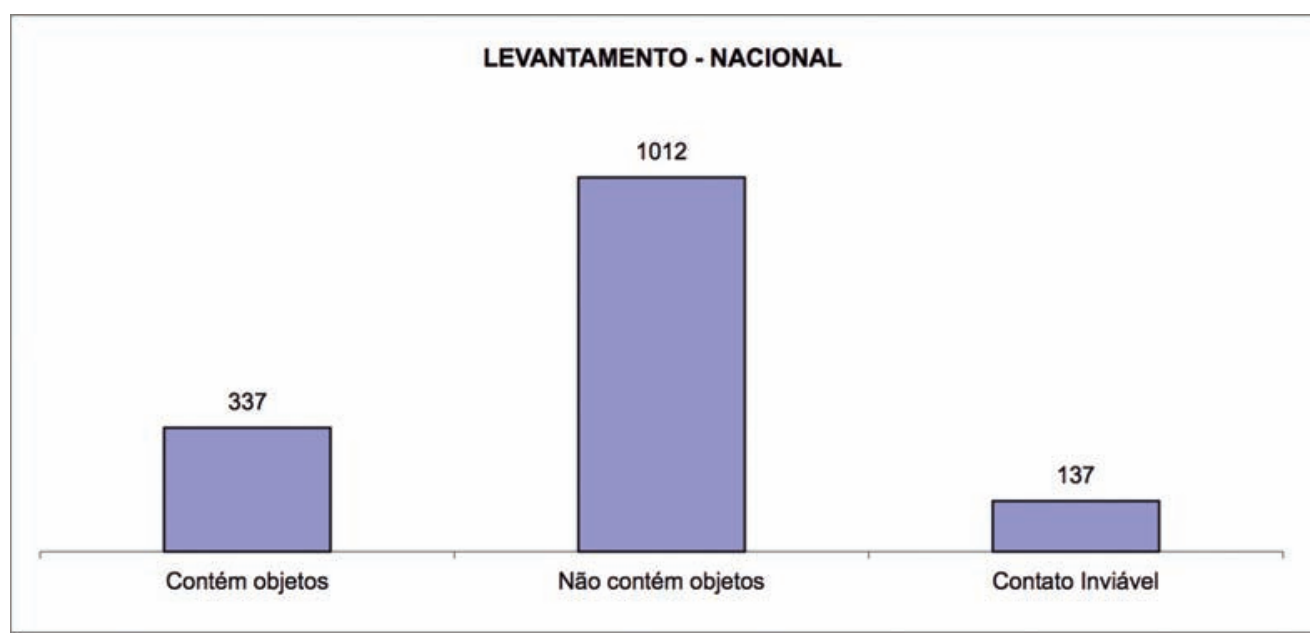

Figura 2: Resultados relacionados à existência ou não de conjuntos de objetos de C\&T nas instituições pesquisadas.

Até o momento 27,337 contatos resultaram na identificação de conjuntos de objetos de C\&T de interesse, correspondendo a 23\% do total de contatos. Em 
relação ao tipo de instituição registrada, 160 são IES (48\%); 139, MUS (41\%); $27, \mathrm{ICT}(8 \%)$ e $11, \operatorname{IEM}(3 \%)$

Dos 1.486 locais identificados, 1.012 , isto é 68\% do levantamento, não possuem objetos de C\&T e, portanto, não foram registrados pelo projeto. Os restantes 137 contatos, 9\% do total, foram inviáveis. Assim, pode-se afirmar que o contato foi possível em $91 \%$ das instituições selecionadas na pesquisa inicial. Esse número resulta do empenho da equipe de projeto que se esforçou para chegar a bom termo nas ligações e visitas realizadas.

Os contatos resultaram num total de mais de 30.000 objetos identificados ${ }^{28}$, que podem ser avaliados em sua distribuição por tipo de instituição no gráfico apresentado na Figura 3 a seguir.

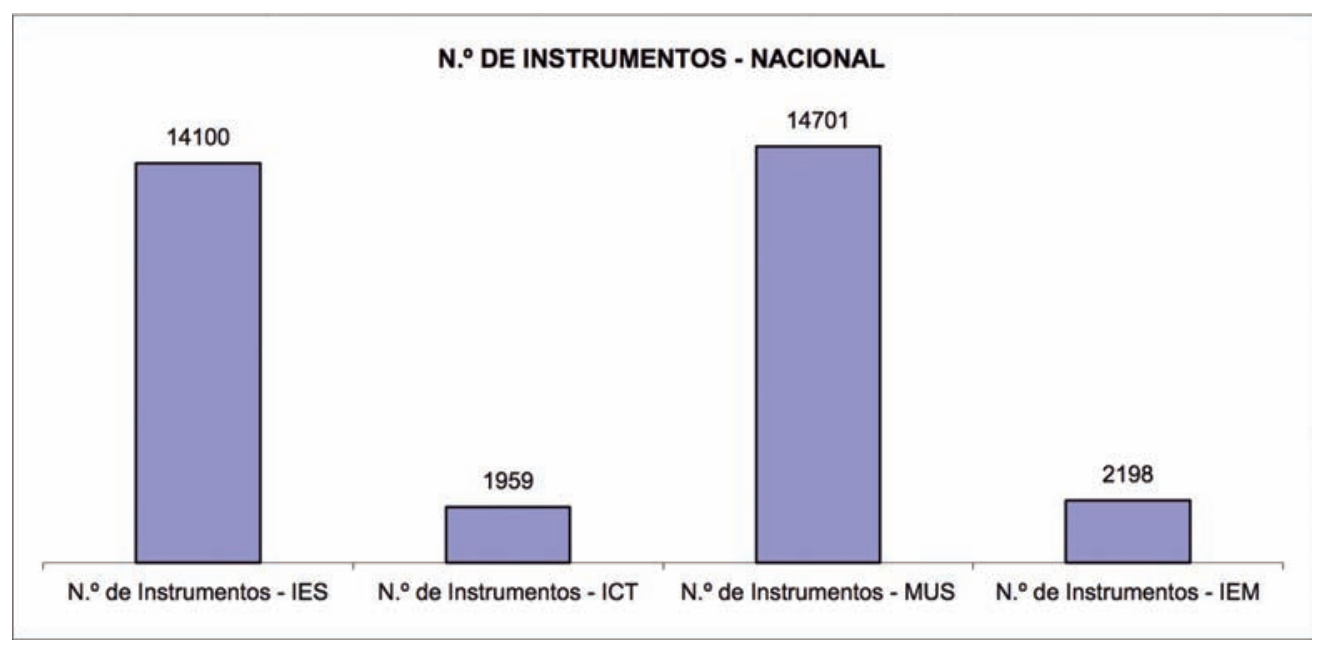

Figura 3: Total de objetos identificados no país, por tipo de instituição (IES - Instituição de Ensino Superior; ICT - Instituições de Pesquisa; MUS - instituições museológicas; IEM - Instituições de Ensino Médio).

Percebe-se, pelo gráfico, que a maioria dos objetos (45\%) felizmente está nos museus (MUS), o que significa que estão minimamente valorados e protegidos; em seguida destacam-se as universidades (IES), com $42 \%$ dos objetos, as instituições de ensino médio, com $6 \%$ do total, e as instituições de pesquisa, com $7 \%$. Esses dados são um indicativo do que foi verificado nas visitas e revelam que as instituições de pesquisa fazem descarte de seus artefatos mais regularmente e têm uma facilidade maior de renovar sua infraestrutura de instrumentos e equipamentos, por isso a presença de objetos antigos e de interesse para o projeto resultou em menor número. Em relação às instituições de ensino médio, os números não são conclusivos, pois os levantamentos não foram priorizados nesses locais, restando boa parte do universo de IEMs a ser identificado e avaliado.

Por outro lado, se calcularmos o número médio de objetos preservado por instituição, em cada tipologia, resultará no seguinte panorama: 71 objetos por
28. É importante destacar que foi retirada desse número a classe de objetos identificada como frascos de reagentes químicos. Em muitos laboratórios químicos visitados e mesmo em alguns museus, como, por exemplo, o Museu da Química Professor Athos da Silveira Ramos (UFRJ), no Rio de Janeiro, foram encontrados muitos frascos antigos de reagentes, com um elevado número de peças que chegava, somente nessa instituição, a cerca de cinco mil artefatos. Caso fossem incluídos, teríamos uma distorção nos números produzidos, em que, provavelmente, a maioria seria desses frascos. Assim, decidiu-se por retirá-los da relação. 
29. Embora a avaliação do estado de conservação a cargo das próprias instituições detentoras dos conjuntos fosse pautada pela explicação detalhada sobre a forma de avaliar e os critérios a serem utilizados, mesmo assim pode ser que o resultado tenha sido subavaliado.
ICT; 86 objetos por IES; 106 objetos por MUS; 198 objetos por IEM. O resultado mostra o potencial significativo das IEM em guardar objetos de interesse, já que em 11 instituições foram identificados mais de 2.000 artefatos.

Apesar do número baixo de objetos preservados por instituição, nas IES, um dado importante é o grande contingente de objetos ali existente, que estão em sua grande maioria em alto risco de perda, pois, com raras exceções, essas instituições não possuem políticas de preservação para esse tipo de patrimônio.

A seguir, a Figura 4 traz um gráfico com a distribuição dos números de presença e ausência de conjuntos de objetos por região do país.

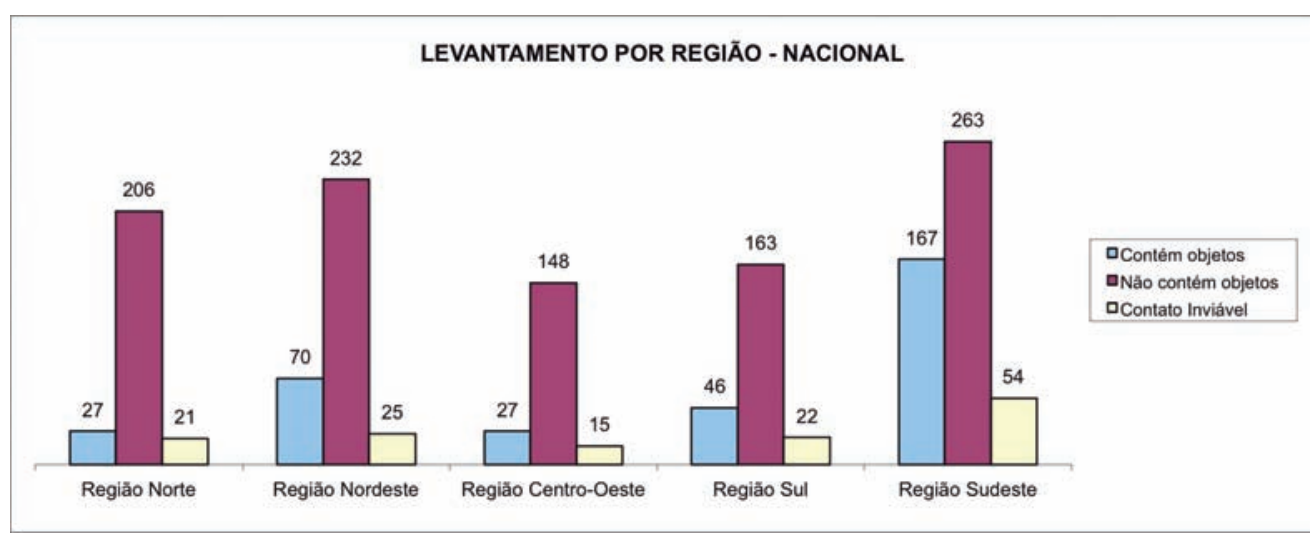

Figura 4: Resultados da presença e ausência de conjuntos de objetos por região do país.

Os resultados apresentados no gráfico mostram que a região com maior percentual de instituições que detêm a posse de conjuntos de objetos de interesse é a Sudeste (50\% do total de instituições contêm objetos), depois vêm as regiões Nordeste (21\%), Sul (13\%), Norte (8\%) e Centro-Oeste (8\%). Esses números revelam certa coerência, pois a região com maior concentração de instituições de pesquisa, e as mais antigas, é de fato a Sudeste. Em seguida, situam-se as regiões com um histórico cada vez mais recente de desenvolvimento e ocupação.

Em relação ao estado de conservação, o gráfico da Figura 5 apresenta os resultados obtidos.

Verifica-se, pela análise do gráfico, que 69\% dos conjuntos identificados estão em situação de conservação boa ou regular. Esse resultado deve, contudo, ser analisado com relatividade, pois, nos locais em que esse parâmetro foi avaliado diretamente por membro da equipe em visita ao local, o dado deve ser mais confiável do que naqueles em que a informação foi obtida a partir da avaliação realizada por pessoal da própria instituição, não raro, sem experiência com esse tipo de abordagem ${ }^{29}$. Também, pelo mesmo motivo, temos tantos conjuntos com avaliação indefinida sobre o estado de conservação. 


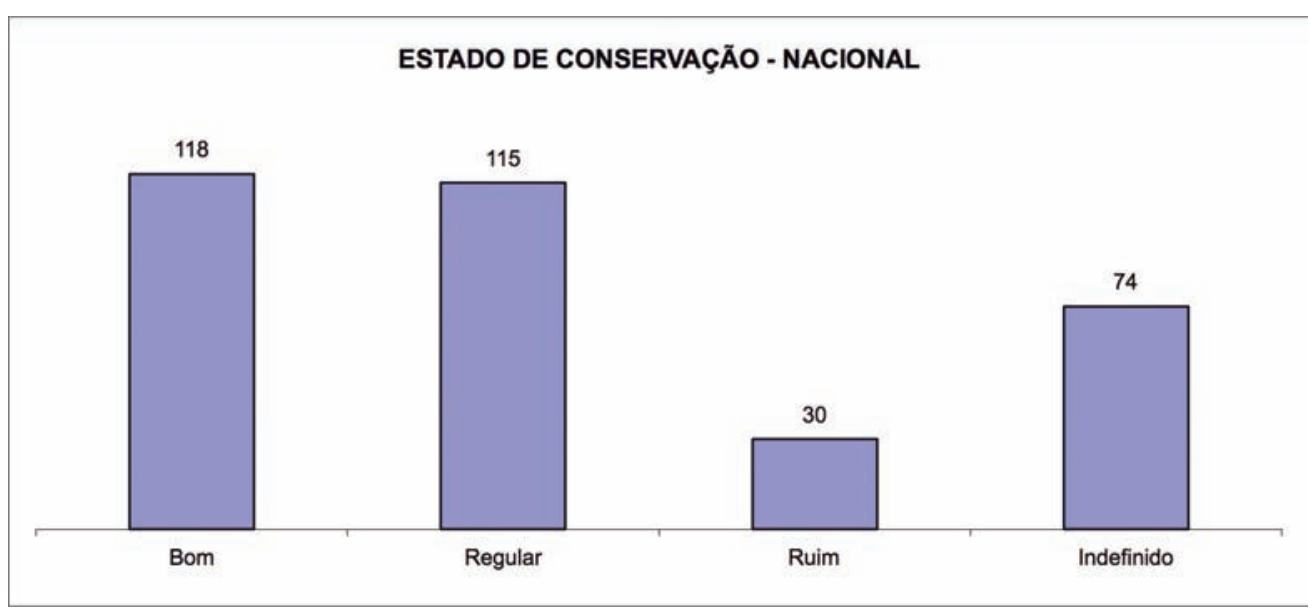

Figura 5: Resultados da avaliação do estado de conservação dos conjuntos identificados.

A partir do cruzamento do gráfico anterior e com os resultados obtidos por região, é possível montar uma tabela (Tabela 2) que revela informações interessantes.

Tabela 2: Resultados percentuais sobre a avaliação do estado de conservação nas diversas regiões do país, em comparação com os dados nacionais.

\begin{tabular}{|l|l|l|l|}
\hline $\begin{array}{l}\text { Estado de conservação } \\
\text { por região }\end{array}$ & $\begin{array}{l}\text { B } O \text { MEGULR (\%) } \\
\text { REcional }\end{array}$ & $\begin{array}{l}|c| \\
\text { NaIM (\%) }\end{array}$ & INDEFINIDO (\%) \\
\hline Sudeste & 69 & 9 & 22 \\
\hline Nordeste & 64 & 8 & 28 \\
\hline Sul & 86 & 4 & 10 \\
\hline Norte & 74 & 4 & 22 \\
\hline Centro-Oeste & 63 & 26 & 11 \\
\hline
\end{tabular}

A região onde o estado de conservação é mais crítico é a Norte, como poderia se esperar, em função das condições climáticas agressivas, com altas temperaturas e umidades relativas, praticamente o ano todo. A região Nordeste apresenta situação singular, com número bastante elevado para objetos em 
30. Por relevante entende-se aqui o grupo de valores atribuídos por terceiros que dão destaque ao conjunto de objetos ou ao objeto específico e que irão interferir decisivamente sobre sua classificação ou não como patrimônio cultural. condições razoáveis de conservação, seguida da região Sul. O número de situações em que não foi possível definir o estado de conservação é muito mais elevado nas regiões Sudeste e Centro-Oeste, sendo menor nas regiões Norte e Nordeste.

Passando ao critério de relevância ${ }^{30}$ atribuída aos conjuntos identificados, fator importante a ser considerado não apenas no estudo, mas também em posteriores políticas públicas para o setor -, foram estabelecidos, nessa pesquisa, cinco níveis de relevância que poderiam estar associados aos conjuntos: internacional, nacional, regional, local e institucional.

No caso dos conjuntos de objetos de C\&T, destacam-se os valores relacionados ao desenvolvimento científico e tecnológico, ou seja, artefatos que foram produzidos no país, ou adquiridos no exterior, e participaram de pesquisas e desenvolvimentos científicos e tecnológicos. Outro aspecto determinante na atribuição de valor diz respeito ao caráter histórico desses objetos. Aqui, inseremse aspectos relacionados à história das instituições que detêm os conjuntos e que poderão resultar em relevância em níveis variados, dependendo da própria atuação institucional no cenário brasileiro e internacional. Outro quesito importante a ser considerado é a raridade do artefato. Aqui está situada a maioria dos protótipos de equipamentos e instrumentos, que são os primeiros a serem elaborados numa linha de desenvolvimento de produto.

Como em toda dimensão subjetiva, a atribuição de relevância e dos valores agregados aos conjuntos levantados é muito relativa e depende sempre de quem atribui os valores. Nas IES, é comum a relevância ser atribuída à importância que os objetos tiveram no ensino e na pesquisa desenvolvidos na instituição. Nos ICT, geralmente a relevância está ligada à importância que a instituição teve em relação à sua área de atuação. Nos museus, costuma estar ligada a alguma personalidade que manteve contato com o objeto, ou à história local, destacandose a atividade que desenvolveu.

Apesar de criado um critério em cinco níveis, foi bastante complexa a tarefa de atribuição de nível de relevância para os conjuntos. Muitas vezes foi solicitado que o responsável pelo conjunto atribuísse a importância ou comentasse sobre o que destacava o conjunto que estava de posse da instituição. Não raro, as respostas eram inconclusivas, pois grande parte desses profissionais não conseguia atribuir valores positivos aos artefatos. A noção de que instrumentos e aparatos antigos têm valor cultural é nova para a maioria dos profissionais que trabalham em laboratórios. A visita de membros da equipe a algumas instituições trouxe, na verdade um efeito positivo nesse aspecto, despertando em muitas pessoas uma nova consciência.

A Figura 6 mostra os resultados obtidos nesse quesito.

Do total de conjuntos registrados, 35\% não apresentaram possibilidade de identificação de sua relevância. $\bigcirc$ que pode ser considerado elevado, apesar da dificuldade intrínseca a esse aspecto. Apenas 3\% dos conjuntos foram correlacionados com relevância internacional. Aqui talvez exista uma subavaliação 


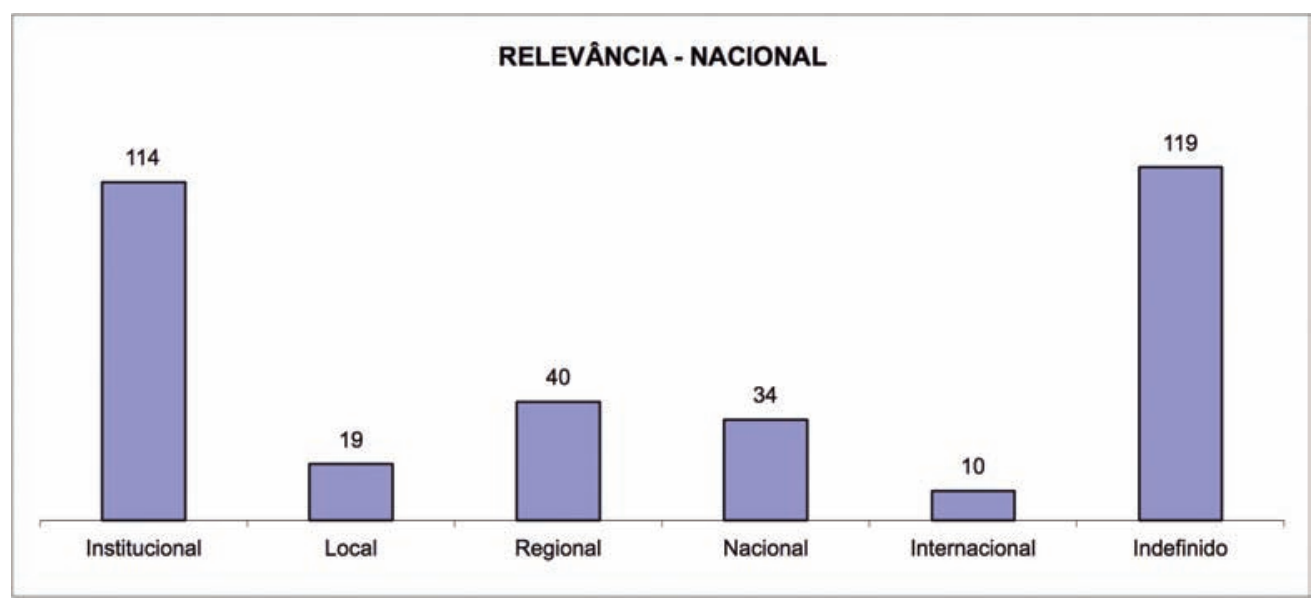

Figura 6: Resultados sobre a relevância atribuída aos conjuntos identificados, por tipo de instituição.

e possivelmente o número real deve ser mais elevado, pela própria significância que a pesquisa brasileira possui no cenário internacional.

Fica claro que é mais fácil identificar os conjuntos com uma pretensa relevância institucional (34\%), já que o maior conhecimento da história institucional pelos avaliadores (profissionais que detêm a guarda dos objetos) permite maior aderência a esse nível do critério.

A seguir serão apresentadas informações coletadas nas visitas realizadas às instituições e que revelam algo mais que os números isolados não permitem identificar.

4. Reflexões sobre a classificação dos conjuntos de objetos de C\&T

As visitas realizadas para identificação dos conjuntos patrimoniais de C\&T possibilitaram verificar uma variedade de situações no que tange inclusive à terminologia utilizada. Percebeu-se a necessidade de propor, discutir e estabelecer uma classificação de termos padronizada e adequada que permita a melhor caracterização desses conjuntos. Muitas vezes, o uso do termo "coleções" é inadequado, pois o grupo de objetos não está submetido a todas as etapas que caracterizam uma coleção. Até mesmo a atribuição de coleção museológica a alguns dos conjuntos encontrados em "museus" é bastante questionável.

Pelo que consta no artigo $1^{\circ}$ do Estatuto de Museus (2009) ${ }^{31}$ a definição de museu abarca uma série de atividades que não se observam em muitos dos museus registrados. $\bigcirc$ estatuto também coloca, no artigo $6^{\circ}$, outra classificação, a de Coleção Visitável, para a qual as determinações da lei não se aplicam:

Art. $1^{\circ}$. Consideram-se museus, para os efeitos desta Lei, as instituições sem fins lucrativos que conservam, investigam, comunicam, interpretam e expõem, para fins de preservação, estudo, pesquisa, educação, contemplação e turismo, conjuntos e coleções de 
32. Brasil (Lei $\mathrm{n}^{\circ} 11.094$, de 14 jan. 2009).

33. Brasil. (Decreto-Lei $\mathrm{n}^{\circ}$ 8.124 de 17 out. 2013).

34. Idem valor histórico, artístico, científico, técnico ou de qualquer outra natureza cultural, abertas ao público, a serviço da sociedade e de seu desenvolvimento.

$(\ldots)$

Art. $6^{\circ}$. Coleções visitáveis: conjuntos de bens culturais conservados por uma pessoa física ou jurídica, que não apresentem as características previstas no art. $1^{\circ}$ desta Lei, e que sejam abertos à visitação, ainda que esporadicamente ${ }^{32}$.

Recentemente, em 17 de outubro de 2013, foi publicado o Decreto 8.12433, que regulamenta dispositivos da referida Lei 1 1.904. Logo no segundo artigo, o documento apresenta outras classificações importantes. Além de ratificar as definições de museu e de coleção visitável, acrescenta as seguintes definições: bens culturais; bens culturais musealizados; bens culturais passíveis de musealização; centro de documentação; degradação; destruição; inutilização; e processo museológico. Todas essas definições estabelecidas no decreto são de grande importância para a elaboração de classificações dos conjuntos encontrados e registrados pela pesquisa aqui apresentada. Para uma reflexão sobre a diversidade do que foi encontrado, especificamente, é necessário ressaltar seis conceitos:

\footnotetext{
Art. $2^{\circ}$ Para fins desse Decreto consideram-se:

I - bens culturais - todos os bens culturais e naturais que se transformam em testemunhos materiais e imateriais da trajetória do homem sobre o seu território;

II - bens culturais musealizados - os descritos no inciso I do caput que, ao serem protegido por museus, se constituem como patrimônio museológico;

III - bens culturais passíveis de musealização - bens móveis e imóveis, de interesse público, de natureza material ou imaterial, considerados individualmente ou em conjunto, portadores de referência ao ambiente natural, à identidade, à cultura e à memória dos diferentes grupos formadores da sociedade brasileira;
}

$V$ - coleção visitável - conjuntos de bens culturais conservados por pessoa física ou jurídica que não apresentem as características previstas nos incisos IX e $X$ do caput, e que sejam abertos à visitação, ainda que esporadicamente;

IX - museu - instituição sem fins lucrativos, de natureza cultural, que conserva, investiga, comunica, interpreta e expõe, para fins de preservação, estudo, pesquisa, educação, contemplação e turismo, conjuntos e coleções de valor histórico, artístico, científico, técnico ou de outra natureza cultural, abertos ao público, a serviço da sociedade e de seu desenvolvimento;

$X$ - processo museológico - programa, projeto e ação em desenvolvimento ou desenvolvido com fundamentos teórico e prático da museologia, que considere o território, o patrimônio cultural e a memória social de comunidades específicas, para produzir conhecimento e desenvolvimento cultural socioeconômico ${ }^{34}$.

Analisando as definições, percebe-se que o artigo trata tanto dos elementos culturais quanto das instituições responsáveis por esses elementos (que podem ser museus, ou não). Define bens culturais, que são elementos materiais ou imateriais transformados em testemunhos da história do homem no seu território, e 
podem estar musealizados ou passíveis de musealização. E também pontua as definições dos locais, espaços, projetos ou instituições onde esses bens se encontram, podendo ser Museus 35 ; espaços denominados de Processo museológico ${ }^{36}$; e Coleção visitáve ${ }^{37}$.

Tendo em vista a situação dos objetos de C\&T nos conjuntos identificados, é indiscutível que todos sejam "bens culturais", pois inegavelmente são testemunhos materiais da trajetória do homem. Não só bens culturais, como boa parte deles também já foi transformada em museália ${ }^{38}$, após serem retirados do circuito econômico e de suas funções enquanto objetos comuns, tornando-se algo que pode ser colecionado e documentado e que está submetido a uma proteção especial. A priori, por estarem alocados em museus, esses conjuntos poderiam ser considerados "bens culturais musealizados", no entanto, a definição de museu determinada na lei nos mostra que nem todos os conjuntos deveriam ser assim definidos. Como diz Panese ${ }^{39}$, os objetos transformados em museália possuem uma capacidade mutável de serem semióforos, isto é, representar o que não está mais presente, o abstrato, estando essa capacidade diretamente relacionada às intervenções realizadas com esses conjuntos.

É necessário que sejam analisadas as ações às quais tais conjuntos estão submetidos, para se ter certeza de que podem ser classificados como coleções museológicas - ou, de acordo com a Lei 8.124, como bens culturais musealizados - e o quanto esses objetos colaboram efetivamente com a área do patrimônio cultural de Ciência e Tecnologia.

Além dessas novas definições, a Lei 8.124 determina um novo dispositivo de proteção, que somado aos já decretados no art. $216^{\circ}$ da Constituição, terá a função de preservar, valorizar e tornar acessíveis à sociedade bens culturais musealizados e passíveis de musealização. Trata-se da Declaração de Interesse Público, discorrida entre os artigos $35^{\circ}$ e $43^{\circ}$ da Lei, no "Título VI DA DECLARAÇÃO DE INTERESSE PÚBLICO"40. No referido título são estipulados o que se consideram bens de interesse público, o processo administrativo declaratório e os efeitos da declaração. Além disso, a lei equipara os bens declarados de interesse público aos bens musealizados, no que concerne à fiscalização das atividades desenvolvidas com eles e aplicação das penalidades, já previstas no artigo $66^{\circ}$ da Lei 11.904 - até então voltada apenas para bens musealizados caso não sejam cumpridas as medidas necessárias à preservação e à correção de danos causados pela degradação, inutilização e destruição.

Dada a sua natureza legal, esse dispositivo será aplicado por meio de processo administrativo que demandará alto grau de conhecimento especializado - incluindo extensa documentação de cunho técnico e comprobatório - e tramitação em diferentes instâncias administrativas e jurídicas, que culminam na homologação a ser realizada pelo Ministro de Estado da Cultura. A obrigação da preservação dos bens de interesse público fica a cargo do proprietário ou responsável pelo bem, que deve adotar as medidas de proteção orientadas pelo IBRAM, notificar seu estado de conservação anualmente, não intervir sem prévia autorização e
35. Instituições culturais abertas ao público, onde continuamente são executadas ações de conservação, investigação, comunicação e exposição, com a finalidade de preservar, desenvolvendo estudos e pesquisas e propiciando a educação, a contemplação e o turismo.

36. Aplicável a situações que podem ou não ter um espaço físico definido, mas que se baseia em teoria e prática museológicas e utiliza-se do patrimônio e da memória social no trabalho com comunidades visando o conhecimento e desenvolvimento cultural e socioeconômico.

37. Conjuntos de bens culturais acessíveis à sociedade, sob a responsabilidade de uma pessoa ou instituição, e que não apresentam as características do museu, nem do processo museológico.

38. Ver Krzysztof Pomian (1984).

39. Ver Francesco Panese (2007).

40. Brasil (Lei ${ }^{\circ} 8.124$, de 17 de outubro de 2013). 
comunicar ao instituto possíveis dificuldades de ordem econômica ou material que impossibilite a garantia da preservação. Os dois primeiros artigos do Título VI estão transcritos a seguir:

Art. 35. A declaração de interesse público de bens culturais, considerados individualmente ou em conjunto, dependerá de homologação do Ministério de Estado da Cultura, após processo administrativo instaurado perante a Presidência do IBRAM, ouvindo - Conselho Consultivo do Patrimônio Museológico.

Parágrafo $1^{\circ}$ Poderão ser declarados de interesse público os bens culturais musealizados e passíveis de musealização, cuja proteção e valorização, pesquisa e acesso à sociedade representarem valor cultural de destacada importância para o País, respeitada a diversidade cultural, regional, étnica e linguística.

Parágrafo $2^{\circ} \mathrm{Em}$ caso de risco à integridade do bem cultural, a declaração de interesse público poderá ser concedida cautelarmente pelo Ministro de Estado da Cultura, ficando a concessão definitiva condicionada ao processo administrativo no âmbito do IBRAM.

Art. $36^{\circ}$. O IBRAM manterá cadastro específico dos bens declarados de interesse público para fins de documentação, monitoramento, promoção e fiscalização, que poderá fazer parte de outros instrumentos da política nacional de museus.

A declaração de interesse público pode ser mais um artifício para proteger do desaparecimento e garantir ações de conservação adequadas para milhares de objetos de C\&T espalhados por salas, laboratórios, depósitos, e outros espaços das universidades e instituições de pesquisa científica e tecnológica. Também é importante tanto para os conjuntos de objetos C\&T que estão em museus, quanto para aqueles que já passaram pelo primeiro processo de seleção e organização, mas ainda devem ser definidos como "bens culturais passíveis de musealização", pois não estão integralmente inseridos em atividades museológicas. Tais conjuntos podem vir a se tornar "bens culturais musealizados", desde que as atividades de pesquisa, documentação, exposição, educação, conservação, etc. se desenvolvam de maneira adequada a este termo.

A Lei 8.124 é de grande relevância, pois, além de definir os bens culturais como musealizados e passíveis de musealização, determina que ambos podem ser declarados de interesse público, o que protege especialmente os bens fora dos museus, já que aqueles declarados de interesse público estão submetidos às mesmas exigências dos bens musealizados.

Vale ressaltar ainda o trabalho de classificação do patrimônio cultural da Universidade de Lisboa, coordenado por Marta Lourenço, entre abril de 2010 e março de 2011 . Para organizar as informações a respeito do patrimônio daquela universidade, foi elaborado um sistema de classificação com duas variáveis. A primeira é Categoria, que define todos os elementos patrimoniais identificados em Coleção, Objeto singular, Museus e Edificação. A segunda variável é um sistema de Classes voltado especificamente para o estado em que as Coleções se 
encontram, considerando o estado do inventário - sendo válido quando pelo menos metade da coleção já estiver com catálogo ou inventário museológico, uma mera listagem não foi considerada -, o estado de conservação e a acessibilidade das coleções. As Classes são assim discriminadas:

Classe I - Coleção por catalogar e inacessível fisicamente;

Classe II - Coleção por catalogar e acessivel fisicamente;

Classe III - Coleção catalogada e acessivel fisicamente;

Classe IV - Catalogada, acessível fisicamente e com standards de conservação.

Através das fichas de registro dos levantamentos realizados e aqui apresentados, é possível obter algumas informações importantes para a reclassificação dos conjuntos. Tendo em vista a necessidade de executar trabalhos de comunicação e exposição ao público, de produção de pesquisa, estudo e documentação, e de conservação dos objetos, para que a coleção possa de fato ser considerada museológica, far-se-á aqui uma proposta de reclassificação desses conjuntos, pois se entende que os mesmos não devem ser automaticamente considerados museológicos por estarem alocados em instituições intituladas "museus".

Para essa nova classificação, serão utilizados os termos "grupo" e "coleção" separadamente, com base na definição de "coleção" colocada por Pomian, e na exclusão do uso desse termo em algumas situações:

(...) uma colecção, isto é, qualquer conjunto de objetos naturais ou artificiais, mantidos temporária ou definitivamente fora do circuito das actividades econômicas, sujeitos a uma protecção especial num local fechado preparado para este fim, e expostos ao olhar do público. É evidente que esta definição tem um caráter rigorosamente descritivo, e é também evidente que as condições que um conjunto de objectos deve satisfazer para que seja possível considerá-lo uma colecção excluem, por um lado, todas as exposições que são apenas momentos do processo da circulação ou da produção dos bens materiais, e, por outro, todas as acumulações de objectos formadas por acaso e também aqueles que não estão expostos ao olhar (como os tesouros escondidos), qualquer que seja o seu carácter $^{41}$.

Ou seja, as "coleções" são compostas por grupos de objetos que foram retirados dos circuitos para os quais foram produzidos, não possuem mais finalidade utilitária, e devem estar acessíveis ao público. Eles estão desligados das atividades econômicas, e submetidos a uma proteção especial ocorrida em local adequado, que thes confere a identidade de objetos preciosos, possuindo, paradoxalmente, um valor de troca, apesar de nunca perderem seu valor de uso ${ }^{42}$. Ainda segundo a definição de Pomian, não podem ser consideradas "coleções": conjuntos de objetos que eventualmente são expostos, mas que não continuam, mesmo que esporadicamente, tendo uso utilitário; conjuntos de objetos acumulados sem intenção de comporem um grupo coeso; e conjuntos de objetos que não estão acessíveis ao público ${ }^{43}$.
41. Ver Krzysztof Pomian (1984, p. 53).

42. Ver Luís Borges e Marcio Campos (2013, p. 122).

43. Ver Krzysztof Pomian (1984, p. 53). 
Tendo em vista essa definição, a legislação brasileira e o trabalho realizado na Universidade de Lisboa, propõem-se, conforme o Quadro 1, as seguintes classificações e definições para os conjuntos de objetos de C\&T:

Quadro 1 - Proposta de classificação de conjuntos de objetos de C\&T.

\section{Denominação}

Grupo de objetos de C\&T não visitável

Er

objetos de C\&T não organizados, que podem ter valor cultural e não passaram por qualquer procedimento de documentação, conservação, pesquisa ou exposição. Encontram-se inacessíveis ao público, podendo estar mesmo abandonados.

Grupo de objetos de C\&T visitável

objetos deliberadamente agrupados por serem considerados valiosos para a cultura científica e tecnológica com mínima organização, expostos ou acessíveis ao público, mesmo que apenas sob marcação de visita.

Coleção visitável

Coleção musealizada

\section{Características}

\begin{tabular}{|c|c|}
\hline & mesmo que apenas sob marcação de visita. \\
\hline Coleção visitável & $\begin{array}{l}\text { objetos que possuem tratamento especial, a começar por terem sido deliberadamente } \\
\text { agrupados por serem considerados valiosos para a cultura científica e tecnológica; } \\
\text { submetidos a uma ou mais atividades museológicas visando a sua preservação, incluindo } \\
\text { listagem e/ou inventário e/ou organização em local adequado para sua preservação } \\
\text { e/ou são utilizados em estudos e pesquisas; expostos ou acessíveis ao público, mesmo } \\
\text { que apenas sob marcação de visita. Não estão inseridos em instituições denominadas } \\
\text { museus, de acordo com o Estatuto dos Museus (2009). }\end{array}$ \\
\hline Coleção musealizada & $\begin{array}{l}\text { objetos deliberadamente agrupados por serem considerados valiosos para a cultura } \\
\text { científica e tecnológica; sob a guarda de um museu e submetidos a todas as etapas de } \\
\text { musealização, que incluem produção de inventário, pesquisa, documentação, exposição, } \\
\text { conservação; e efetivamente enquadrados na definição de "bens culturais musealizados" } \\
\text { (item II, artigo } 2^{\circ} \text {, Decreto-Lei } 8124 \text {, de } 17 \text { de outubro de 2013). }\end{array}$ \\
\hline
\end{tabular}

A partir dessa classificação, em breve serão revistos todos os conjuntos de objetos de C\&T identificados no levantamento realizado, de forma a permitir uma melhor compreensão, explicitada na própria nomenclatura, e em suas principais características. Assim, julga-se será possível também estabelecer 
prioridades de investimento, caso se elabore uma política de preservação desses conjuntos que inclua editais de financiamento para sua preservação. Esse exercício de classificação permitirá ainda avaliar se as classes sugeridas no Quadro I são suficientes e se estão bem caracterizadas. Do contrário, a experiência potencialmente possibilitará o aprimoramento da classificação.

\section{Considerações finais}

Os resultados aqui apresentados são importantes para a preservação do patrimônio cultural de ciência e tecnologia, pois constituem o primeiro registro geral desses conjuntos de objetos, documentando a situação atual desse patrimônio no país. Essas informações mostram-se especialmente relevantes, se pensarmos que parte desses objetos de C\&T pode deixar de existir a qualquer momento, à mercê da necessidade de espaço pelas instituições ou da pressão por equipamentos mais recentes que costuma determinar o descarte. Assim, torna-se fundamental registrar e divulgar a existência desses objetos ${ }^{44}$ e colaborar para que políticas de preservação sejam estruturadas em nível local e também nacional.

Boa parte dos objetos identificados na pesquisa está minimamente preservada nos museus (45\%), porém, nem todas as instituições que se propõem a ser museus, ou que assim se autodenominam, conseguem se enquadrar plenamente nessa categoria ${ }^{45}$. Essa impossibilidade pode ter uma série de causas: a falta de recursos financeiros e humanos; a falta de espaço adequado; a falta de prioridade da instituição a qual estão vinculados; e, inclusive, a falta de interesse em praticar todas as ações que deveriam ser primordiais em museus, limitando-se a salvar do descarte peças consideradas importantes e promover seu acesso ao público. Portanto, o uso de outras nomenclaturas, como memoriais, exposições, coleções visitáveis, etc., poderia ser adotado, sem demérito do trabalho realizado. Por outro lado, em muitos casos, a denominação de "museus" torna-se importante para o reconhecimento institucional e, muitas vezes, para a própria sobrevivência do espaço de salvaguarda do patrimônio cultural de C\&T, especialmente no âmbito das IES.

Observou-se, com os contatos e visitas realizados ao longo do projeto, um movimento de esclarecimento e de tomada de consciência por certo número pessoas que lidam, no cotidiano, com esse patrimônio; elas passaram não só a olhar os objetos de outra forma, como também a pensar em caminhos e saídas para a sua preservação. Nesse sentido, esse efeito "colateral" do projeto mostrouse muito positivo, e pode ser responsável pela salvaguarda de muitos objetos pelo país.

Tendo em vista tal situação, considerou-se ainda a emergência de realizar atividades que colaborassem com os profissionais interessados em preservar esses artefatos, mas que, em sua maioria, não sabem como fazê-lo, e de conscientizar as diretorias e reitorias das instituições da importância desses artefatos
44. É importante ressaltar que, nas visitas da equipe do projeto às universidades e aos institutos de pesquisa, era comum encontrar objetos que estavam aguardando o fim das etapas do processo burocrático para o descarte. As universidades, em muitos casos, informaram ter recém-descartado um grande volume de aparatos científicos históricos, principalmente após a entrada da verba do Reuni, que possibilitou a muitos centros e institutos acadêmicos a renovação de seu material laboratorial.

45. A definição de museu, apresentada no artigo $1^{\circ}$ do Estatuto de Museus (2009), abarca uma série de atividades que não se observam em muitos dos museus registrados - "Consideram-se museus, para os efeitos desta Lei, as instituições sem fins lucrativos que conservam, investigam, comunicam, interpretam e expõem, para fins de preservação, estudo, pesquisa, educação, contemplação e turismo, conjuntos e coleções de valor histórico, artístico, científico, técnico ou de qualquer outra natureza cultural, abertas ao público, a serviço da sociedade e de seu desenvolvimento".

46. Já foi elaborada uma cartilha para orientação daqueles que têm a responsabilidade sobre esses artefatos, contendo informações gerais e instruções sobre preservação de acervos de C\&T (Marcus Granato e Colaboradores, 2013). A cartilha é de acesso gratuito e está disponível nas páginas da internet do MAST e do Projeto Valorização. 
para a história da ciência institucional e nacional. Nessa perspectiva, colocam-se a elaboração de uma cartilha para preservação de acervos de C\&T46 e o desenvolvimento de uma base de dados informatizada para inserção dos conteúdos das fichas de registro.

As ações até aqui desenvolvidas se complementam com a proposta de divulgação futura dos conjuntos de objetos de C\&T encontrados através de publicações, palestras e exposições. Outra iniciativa que viria a colaborar para a salvaguarda desses bens é a disponibilização gratuita de um software de registro para esse tipo de objetos, com o objetivo de, em médio prazo, conferir-thes visibilidade junto a uma parcela maior da sociedade, através da internet. Essa segunda base de dados, então individualizada por objeto registrado, tem por finalidade possibilitar, pelo menos, a produção de listas de objetos nos locais onde estão situados e, se houver interesse da instituição detentora da posse dos objetos, integrá-los numa plataforma digital que será disponibilizada pelo MAST. Nesse caso, o acesso do visitante virtual permitirá visualizar todos os objetos que estiverem disponibilizados pelas instituições.

○ comprometimento com os estudos e ações que ampliam o conhecimento e a divulgação do patrimônio científico é o caminho para o reconhecimento de sua importância e para a constituição de diretrizes capazes de orientar aqueles que querem preservar, mas não sabem como fazer. Trata-se, pois, da maneira mais eficaz para sensibilizar os atores sociais e políticos na direção da criação de políiticas e linhas de financiamento, como no exemplo alemão, que viabilizem a permanência desses objetos no tempo.

Por fim, cabe ressaltar que estão sendo feitas gestões junto ao Ministério da Cultura e ao Ministério da Ciência, Tecnologia e Inovação, no sentido de criar uma política de Estado para preservação dessa tipologia de patrimônio cultural.

\section{Agradecimentos}

Os autores agradecem os apoios do Conselho Nacional de Desenvolvimento Científico e Tecnológico - CNPq e da Fundação de Amparo à Pesquisa no Estado do Rio de Janeiro - FAPERJ para o desenvolvimento das pesquisas, sem os quais teria sido impossível realizar este trabalho. 


\section{ANEXO}

Ficha de Registro de Conjuntos de Objetos de C\&T

\begin{tabular}{|c|c|}
\hline \multicolumn{2}{|c|}{ FICHA MATRIZ - CONJUNTOS DE OBJETOS DE C\&T } \\
\hline Designação & $\begin{array}{l}\text { Inserir a designação corrente da coleção, ex.: Acervo de } \\
\text { Instrumentos de Ensino de Física. }\end{array}$ \\
\hline Dimensão & Inserir número estimado de artefatos ou objetos. \\
\hline Número & $\begin{array}{l}\text { Número de série do levantamento. A ser preenchido por } \\
\text { pesquisador do projeto (número sequencial - sigla da } \\
\text { instituição - ano do preenchimento da ficha, ex.: } \\
\text { o0ı1MCT2010). }\end{array}$ \\
\hline Instituição & $\begin{array}{l}\text { Inserir a designação da instituição de tutela (ex.: Museu de } \\
\text { Astronomia e Ciências Afins, Universidade Federal do Rio de } \\
\text { Janeiro, Escola Secundária Bento de Abreu). }\end{array}$ \\
\hline Unidade de tutela direta & $\begin{array}{l}\text { Inserir a designação do Laboratório, Departamento, Centro } \\
\text { de Pesquisa, Museu. }\end{array}$ \\
\hline Localização & Inserir o local onde a coleção se encontra. \\
\hline Website & $\begin{array}{l}\text { Inserir website relativo à coleção ou website relevante (se } \\
\text { aplicávell. }\end{array}$ \\
\hline Diretor/Responsável & $\begin{array}{l}\text { Inserir o nome e posição do responsável, conservador ou, em } \\
\text { última análise, diretor/presidente da instituição de tutela } \\
\text { direta. }\end{array}$ \\
\hline Contato & Email ou telefone do nome inserido no campo anterior. \\
\hline $\begin{array}{l}\text { Enquadramento institucional } \\
\text { e legal }\end{array}$ & $\begin{array}{l}\text { Inserir se a coleção é propriedade da instituição ou se está } \\
\text { em depósito. Referir se existem referências à coleção no } \\
\text { estatuto ou regulamento da instituição. Referir outros } \\
\text { documentos legais ou institucionais relevantes para a coleção. }\end{array}$ \\
\hline
\end{tabular}


Alguns exemplares da coleção:

\begin{tabular}{|c|c|}
\hline \multicolumn{2}{|c|}{ Foto 1} \\
\hline $\begin{array}{l}\text { Nota descritiva e } \\
\text { histórica }\end{array}$ & $\begin{array}{l}\text { Inserir um breve parágrafo sobre a história da coleção (data aproximada } \\
\text { da constituição, razões da constituição, fins a que se destinou/destina ao } \\
\text { longo do tempo, localizações e mudanças). MÁXIMO } 300 \text { PALAVRAS. }\end{array}$ \\
\hline Relevância & $\begin{array}{l}\text { Inserir um breve comentário sobre a relevância histórica, científica do } \\
\text { coleção nos dias de hoje. Mencionar igualmente caso a coleção tenha } \\
\text { importância internacional. Identificar objetos ou conjuntos de objetos } \\
\text { particularmente significativos. MÁXIMO } 300 \text { PALAVRAS. }\end{array}$ \\
\hline Utilização & $\begin{array}{l}\text { Inserir usos recentes ou regulares da coleção (ex.: ensino, investigação, } \\
\text { exposição). MÁXIMO } 200 \text { PALAVRAS. }\end{array}$ \\
\hline Estado do inventário & $\begin{array}{l}\text { Inserir se a coleção está inventariada ou não, no todo ou em parte. Referit } \\
\text { se o inventário é em suporte informático ou em papel (manuscrito ou } \\
\text { datilografado). Referir igualmente se o inventário está acessível online, em } \\
\text { catálogo impresso ou digital (DVD ou CDROM). }\end{array}$ \\
\hline Documentação & $\begin{array}{l}\text { Referir se a coleção possui documentação associada lex.: um arquivo e } \\
\text { referir quall e se essa se encontra organizada. }\end{array}$ \\
\hline $\begin{array}{l}\text { Estado de } \\
\text { conservação }\end{array}$ & $\begin{array}{l}\text { Inserir dados relativos ao estado geral de conservação (mau estado, } \\
\text { razoável, bom estado; no todo ou em parte). Inserir pormenores relevantes } \\
\text { (ex.: peças incompletas, peças com fungos ou pestes). Inserir informação } \\
\text { relativa às condições ambiente (controladas ou não) e armazenamento. } \\
\text { Referir intervenções recentes de conservação e/ou restauro. }\end{array}$ \\
\hline Pessoal & $\begin{array}{l}\text { Pessoal relacionado diretamente ao acervo, tipo de posição (do quadro, } \\
\text { contrato de prestação, bolsista, etc.) e qualificação. }\end{array}$ \\
\hline Observações & $\begin{array}{l}\text { Campo livre para inserção de outra informação relevante. MÁXIMO } 300 \\
\text { PALAVRAS. }\end{array}$ \\
\hline Bibliografia & $\begin{array}{l}\text { Inserir bibliografia direta sobre a coleção (catálogos, estudos). Não inserit } \\
\text { bibliografia indireta (em que a coleção aparece referida ocasional ou } \\
\text { marginalmente). } \\
\text { MÁXIMO } 4 \text { REFERÊNCIAS. }\end{array}$ \\
\hline Autor da ficha & Inserir identificação e contato do autor/a da ficha. \\
\hline $\begin{array}{ll}\text { Data } & d e \\
\text { preenchimento } & \end{array}$ & Inserir data de conclusão de preenchimento da ficha. \\
\hline
\end{tabular}

Dificuldades ou dúvidas no preenchimento:

Por favor, contate Marcus Granato Museu de Astronomia e Ciências Afins-MAST): marcus@mast.br ou por telefone: 2135145213. 


\section{REFERÊNCIAS}

BALLÉ, Catherine; CUENCA, Catherine; THOULOUZE, Daniel (ed.). Patrimoine scientifique et technique. Un projet contemporain. Paris: La Documentation Française, 2010.

BENNETT, Jim A. Museums and the History of Science. ISIS, Chicago, v. 96, n. 4, p. 602-608, dez. 2005.

BORGES, Luiz C.; CAMPOS, Marcio D'Olne. Patrimônio como valor, entre ressonância e aderência. IN: SCHEINER, Tereza; GRANATO, Marcus; REIS, Maria Amélia de Souza; AMBROCY, Gladys Barrios (Orgs.). Icomfom Lam 2012: termos e conceitos da museologia: museu inclusivo, interculturalidade e patrimônio integral. Rio de Janeiro: MAST, 2012. p. 112-123. Disponível em: http://www.youblisher.com/p/736266-Livro-ICOFOM-LAM-2012/. Acesso em 14 jul. 2014.

BRASIL. Portaria Normativa $N^{o}$ 40, de 12 de dezembro de 2007. Disponível em: http://meclegis.mec.gov.br/documento/view/id/17/. Acesso em 24 jul. 2013.

Lei No 11.904, de 14 de janeiro de 2009. Estatuto de Museus. Disponível em: http:// www.planalto.gov.br/ccivil_03/_Ato2007-2010/2009/Lei/L11904.htm. Acesso em 25 fev. 2014.

Decreto-Lei 8124, de 17 de outubro de 2013. Disponível em: http://www.planalto. gov.br/ccivil_03/_Ato2011-2014/2013/Decreto/D8124.htm. Acesso em 25 fev. 2014.

CAPES - Coordenação de Aperfeiçoamento de Pessoal de Nível Superior. Tabela de Áreas de Conhecimento. 2012. Disponível em: http://www.capes.gov.br/images/stories/download/ avaliacao/TabelaAreasConhecimento_072012.pdf . Acesso em 30 jul. 2013.

GIRES, Francis; Lauginie, Pierre. Preserving the Scientific and Technical Heritage of Education: the ASEIST. Museologia e Patrimônio, Rio de Janeiro, v.6, n.1, p.161-178, 2013.

GRANATO, Marcus. Panorama sobre o patrimônio de Ciência e Tecnologia no Brasil: Objetos de C\&T. In: GRANATO, Marcus; RANGEL, Marcio F. Cultura material e patrimônio de ciência e tecnologia. Rio de Janeiro: MAST, 2009. p. 78-102.

GRANATO, Marcus; LOURENÇO, Marta C. (org.). Coleções científicas luso-brasileiras: patrimônio a ser descoberto. 1ed. Rio de Janeiro: MAST, 2010. Disponível em: http://www.mast.br/livros/ colecoes_cientificas_luso_brasileiras_patrimonio_a_ser_descoberto.pdf. Acesso em 02 fev. 2014.

GRANATO, Marcus; LOUVAIN, Pedro. Legislação de Proteção ao Patrimônio Cultural de Ciência e Tecnologia: análise e proposições. In: Granato, Marcus; Scheiner, Tereza Cristina Molleta (Orgs.). IV Seminário de Pesquisa em Museologia dos Países de Língua Portuguesa e Espanhola (IV SIAM). Museologia, Patrimônio, Interculturalidade: museus inclusivos, desenvolvimento e diálogo intercultural. Textos selecionados. 1ed. Rio de Janeiro: Museu de Astronomia e Ciências Afins, 2013. v. 2, p. 234-249. Disponível em: http://www.youblisher.com/p/771560Livro-IV-SIAM-2012/. Acesso em 02 fev. 2014.

GRANATO, Marcus; RIBEIRO, Emanuela Sousa; CERAVOLO, Suely; HANDFAS, Ethel. Cartilha de Orientações Gerais para Preservação do Patrimônio Cultural de Ciência e Tecnologia, Rio de Janeiro: MAST, 2013. Disponível em: http://www.mast.br/pdf/cartilha_de_orientacoes_gerais_para_preservacao_do_patrimonio_cultural_de_ciencia_e_tecnologia_v2.pdf. Acesso em 28 dez. 2013.

GRANATO, Marcus et. al. Objetos de ciência e tecnologia como fontes documentais para a história das ciências: resultados parciais. In: VIII Encontro Nacional de Pesquisa em Ciência da Informação, 2007, Salvador. Anais do VIII Encontro Nacional de Pesquisa em Ciência da Informação. Brasília: ANCIB, 2007. v. 1, p. 1-16. 
GRANATO, Marcus et. al.. Valorização do patrimônio científico e tecnológico brasileiro: resultados de pesquisa. In: XIII Encontro Nacional de Pesquisa em Ciência da Informação, 2013, Florianópolis. Anais do XIII Encontro Nacional de Pesquisa em Ciência da Informação. Florianópolis: UFSC, 2013a. v. 1, p. 1-20.

Thesaurus de acervos científicos como instrumento de preservação do patrimônio científico: um projeto de cooperação luso-brasileira. In: IV Encontro de Museus de Países e Comunidades de Língua Portuguesa, 2013, Lisboa. Atas do IV Encontro de Museus de Países e Comunidades de Lingua Portuguesa. Lisboa: Comissão Nacional Portuguesa do ICOM, 2013b. v. 1, p. 93-102.

LOURENÇO, Marta; WILSON, Lydia. Scientific Heritage: Reflections on its Nature and New Approaches to Preservation, Study and Access. Studies in History and Philosophy of Science, Oxford / Nova York, v. 44, n. 4, p. 744-753, dez. 2013.

LOUVAIN, Pedro; GRANATO, Marcus. Legislação brasileira de proteção ao patrimônio cultural de ciência e tecnologia: análise e aplicação no ensino e pesquisa. In: II Seminário Gestão do Patrimônio Cultural de Ciência e Tecnologia, 2013, Recife. Anais do II Seminário Gestão do Patrimônio Cultural de Ciência e Tecnologia. Recife: Editora Universitária da UFPE, 2013. v. 1, p. 138-165.

OLIVEIRA, Maria Alice Ciocca de; GRANATO, Marcus. A trajetória da formação da coleção de objetos de ciência \& tecnologia do Observatório do Valongo. In: XII Encontro Nacional de Pesquisa em Ciência da Informação, 2011, Brasília. Anais do XII ENANCIB. Brasília: UNB; ANCIB, 2011. v. 1, p. 2.753-2.767.

The Historical Instruments from Valongo Observatory, Federal University of Rio de Janeiro. University Museums and Collections Journal, Berlin, v. 5, p. 53-64, 2012. Disponível em:http://edoc.hu-berlin.de/umacj/2012/oliveira-53/PDF/oliveira.pdf. Acesso em 02 fev. 2014.

POMIAN, Krzysztof. Colecção. In: Enciclopedia Einaudi, v. 1. Lisboa: Imprensa Nacional/ Casa da Moeda, 1984. p. 51-86.

PANESE, Francesco. O significado de expor objetos científicos em museus. In: VALENTE, Maria Esther Alvarez (org). Museus de Ciência e Tecnologia - interpretações e ações dirigidas ao público. Rio de Janeiro: MAST, 2007. p. 31-39.

SCHEINER, Teresa. Políticas e diretrizes da museologia e do patrimônio na atualidade. In: BITTENCOURT, José Neves; GRANATO, Marcus; BENCHETRIT, Sarah Fassa (org.). Museus, ciência e tecnologia. Rio de Janeiro: Museu Histórico Nacional, 2007. p. 31-48.

SCIENTIFIC Collections as Research Infrastructure, German Council for the Sciences and Humanities, Disponível em: http://www.wissenschaftsrat.de/download/archiv/10464-11-11_ engl.pdf. Acesso em 13 fev. 2014.

SOUBIRAN, Sebastien; LOURENÇO, Marta; WITTJE, Roland; TALAS, Sofia; BREMER, Thomas. Initiatives européennes et patrimoine universitaire. La Lettre de l'OCIM, Dijon, n.123, p.5-14, 2009.

ZAUZIG, Oliver. The Documentation of University Collections in Germany. eRittenhouse, Windsor, v. 24, p. 1-7, 2013. Disponível em:http://www.erittenhouse.org/artitcles/current-issue-vol-24-2/university-collections-in-germany/. Acesso em 13 fev. 2014.

\section{Artigo apresentado em 09/2014. Aprovado em 12/2014.}

